\title{
TRACTIVE DEMAND, SOIL MOBILIZATION PARAMETERS, AND CORN YIELD IN COMPACTED OXISOL
}

\author{
Jônatan Müller', Alcir J. Modolo", Robson G. Trentin ${ }^{3}$, José R. da R. Campos ${ }^{3}$, Murilo M. Baesso ${ }^{4}$ \\ ${ }^{2 *}$ Corresponding author. Universidade Tecnológica Federal do Paraná/ Pato Branco - PR, Brasil. E-mail: alcir@utfpr.edu.br \\ ORCID ID: https://orcid.org/0000-0002-4796-8743
}

\section{KEYWORDS}

direct seeding, ground cover plants, shank working depth.

\begin{abstract}
Direct seeding systems are characterized by soil disturbance only occurring in the sowing line and the maintenance of the remaining area is achieved by covering with crop residues. Without total area soil mobilization as recommended by the no-tillage system, associated with the increase in the degree of soil compaction caused by the traffic of agricultural machinery, there can be a decrease in crop productivity. This study aimed to evaluate machine parameters, soil mobilization, and corn yield as a function of different furrow opener working depths $(0.065,0.095,0.125$, and $0.150 \mathrm{~m})$ and evaluate the direct seeding of winter ground cover plants (black oat or forage turnip) in compacted Oxisol. The experiment was arranged in strips, in a randomized block design, with eight treatments and four replications. The deepening of the furrow opener shank increased the strength and power required at the drawbar in the seeding operation, as well as increased the soil mobilization in the seeding line. However, it did not prove to be an efficient management practice to increase corn productivity.
\end{abstract}

\section{INTRODUCTION}

No-tillage is characterized by minimum tillage and the maintenance of soil cover with crop residues. However, the minimum mobilization of soil associated with the pressure accumulation exerted by the traffic of machines has caused an increase in soil compaction (Debiasi et al., 2010; Couto et al., 2013; Feitosa et al., 2015).

The alteration of the soil structure characterizes compaction due to the reorganization of the particles and aggregates, usually resulting in an increase in soil density and a decrease in total porosity (Valadão et al., 2015). The degree of soil compaction governs the modification of its attributes, i.e., the rate of infiltration, redistribution of water, compromising of gas flow, and nutrient absorption in the soil. These changes in soil attributes may restrict the development of the root system and aerial part of plants (Collares et al., 2008), causing a decrease in crop productivity (Gubiani et al., 2014).

Scarification is an alternative to minimize the possibility of productivity loss caused by soil compaction, but it does not characterize the no-tillage system. With this in mind, the possibility of increasing the soil mobilization in the sowing line arises through the deepening of the fertilizer shank.
Nunes et al. (2015) verified a greater mass and length of corn roots when the furrow opener shank worked at a depth of $0.17 \mathrm{~m}$, in relation to the lowest depth $(0.05 \mathrm{~m})$, in Oxisol with $61 \%$ clay in which direct seeding had been performed for over 10 years. However, this practice usually demands greater tractive force to increase soil decompression in the seeding line (Tricai et al., 2016), resulting in a decrease in operating efficiency, mainly due to the higher demand for traction (Palma et al., 2010).

In addition to mechanical handling, ground cover plant cultivation appears to be appropriate to mitigate soil compaction in direct seeding. Among cover crops, Avena strigosa (black oats) stand out because of a high dry matter yield, tolerance to water deficit, and weed control (Altieri et al., 2011). Another species with a desirable characteristic is Brassica rapa $L$. (forage turnip), because it has a pivoting radicular system and high production of biomass, when compared to black oats, ryegrass, and vetch (Sanchez et al., 2012).

In this context, Santos et al. (2014) show the use of winter ground cover crops to be favorable, since reducing machine traffic is not enough to minimize soil compaction in a direct seeding system. The authors state that the adoption of crop rotation, with the use of winter ground

\footnotetext{
${ }^{1}$ Instituto Federal do Rio Grande do Sul/ Bento Gonçalves - RS, Brasil

${ }^{3}$ Universidade Tecnológica Federal do Paraná/ Pato Branco - PR, Brasil.

${ }^{4}$ Universidade de São Paulo/ Pirassununga - SP, Brasil.

Received in: 10-31-2017

Accepted in: 10-31-2018
} 
cover crops which have a voluminous and deep root system, is essential to reduce soil compaction.

Thus, the aim of this study was to evaluate tractive demand, soil mobilization parameters, and corn productivity as a function of the furrow opener's shank working depth $(0.065,0.095,0.125$, and $0.15 \mathrm{~m})$ and cultivation with winter ground cover plants (black oat and forage turnip) in compacted Oxisol, in a direct seeding system.

\section{MATERIAL AND METHODS}

The experiment was conducted during the 2014/2015 season, in Typic Hapludox (Soil Survey Staff, $2014)$ with a predominantly clay-like texture $(77.4 \%$ clay, $20.3 \%$ silt, and $2.3 \%$ sand). The climate is subtropical humid, type Cfa according to the Köppen classification. The area is located on the Southwest of Paraná State - Brazil (Figure 1), with an average elevation of $760 \mathrm{~m}$ and maximum slope of $3 \%$.

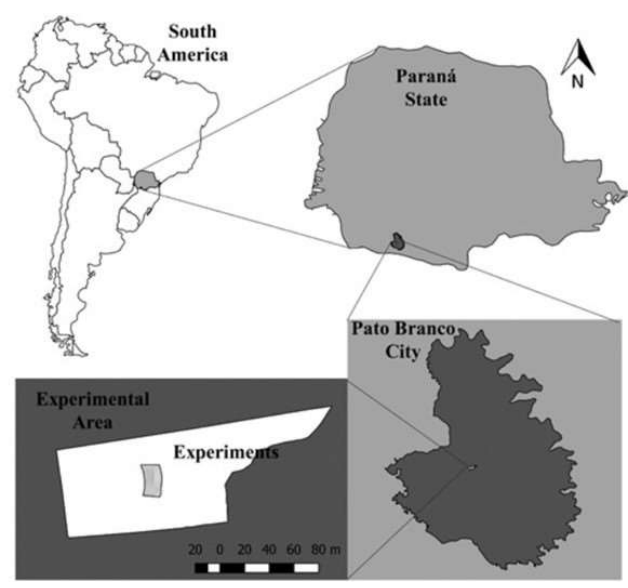

FIGURE 1. Geographic location of the experimental area. Pato Branco, PR.

Data on the mean temperature, rainfall, and corn crop evapotranspiration calculated according to the methodology of Thornthwaite (1948) over the course of the experiment are presented in Figure 2.

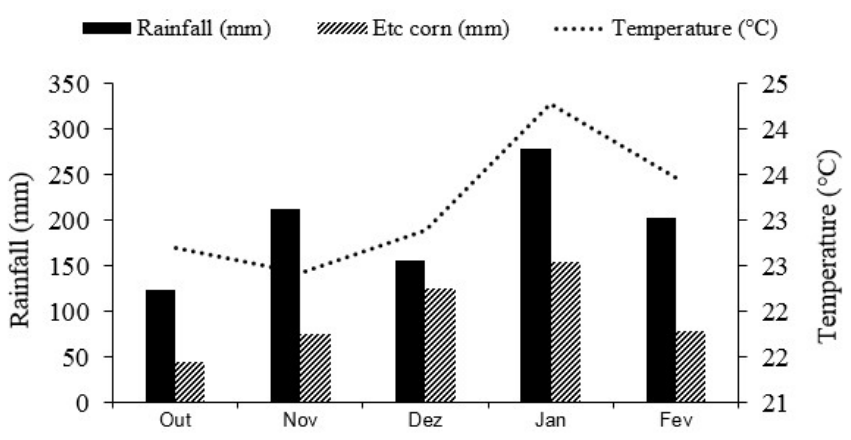

FIGURE 2. Rainfall (mm), evapotranspiration (Etc), and temperature $\left({ }^{\circ} \mathrm{C}\right)$ that occurred during the stages of corn crop development between 2014 and 2015.

Source: Instituto Agronômico do Paraná (IAPAR).

The experiment was conducted in strips, in a randomized block design, with eight treatments and four replicates, totaling 32 experimental units, each with an area of $52.5 \mathrm{~m}^{2}(3.5 \mathrm{~m} \times 15.0 \mathrm{~m})$. The main treatments were composed of the four shank working depths $(0.065,0.095$, 0.125 , and $0.150 \mathrm{~m}$ ) and the secondary treatments were composed of the cultivation of two winter ground cover plants (black oats and forage turnip).

Soil compaction was accomplished by tractor tires passing over the same track, until the whole area of the experiment was compacted. A New Holland ${ }^{\circledR}$ TL75E 4x2 AFWD (Auxiliary Front Wheel Drive) tractor was used, with a total load of $4,630 \mathrm{~kg}$, standard diagonal $12.4 \times 24$ front tires, and $18.4 \times 30$ rear tires. A Jacto, AM-12 $(250 \mathrm{~kg})$ sprayer supplied with 600 liters of water was also fitted to the tractor's three-point hitch system, totaling a mass of $5,480 \mathrm{~kg}$.

The contact area of the front tires and rear tires with the ground was obtained through digital image processing with the SisCob 1.0 program, made available by Embrapa Instrumentação Agropecuária (CNPDIA). The methodology consisted of positioning the tractor in the experimental area and applying limestone around the tractor tires, with subsequent displacement of the tractor to register the images. The mean pressures of the rear and front tires over the ground were $197 \mathrm{kPa}$ and $125 \mathrm{kPa}$, respectively, obtained by dividing the load of each tire by the respective area of ground contact. The compaction was performed when the soil presented gravimetric moisture of $39 \%$.

The average soil density after compaction was 1.20 $\mathrm{Mg} \mathrm{m} \mathrm{m}^{-3}$. This value was obtained via an average of 64 samples randomly collected from the experimental units, 32 in the 0.03-0.07 m layer depth and 32 in the $0.12-0.15 \mathrm{~m}$ layer depth, with volumetric rings of 0.03 and $0.05 \mathrm{~m}$ in height and diameter, respectively.

The average relative soil density was 0.93 , which is considered restrictive to the development of the root system of grain crops (Klein, 2014). This result was obtained by dividing the apparent density of the soil $\left(1.20 \mathrm{Mg} \mathrm{m}^{-3}\right)$ by the maximum density $\left(1.29 \mathrm{Mg} \mathrm{m}^{-3}\right)$ obtained by the normal proctor test.

After soil compaction, without the use of furrow fertilization the black oats and forage turnip were sown on $05 / 23 / 2014$, with 100 and $16 \mathrm{~kg} \mathrm{ha}^{-1}$ of seeds, respectively. After the plants emergence, $30 \mathrm{~kg} \mathrm{ha}^{-1}$ of $\mathrm{N}$ (urea) was applied across the experimental area. When the crops were in the phenological stage of full bloom and beginning of grain filling, a dose of $3.0 \mathrm{~L} \mathrm{ha}^{-1}$ of Glyphosate was sprayed to cause the senescence of the winter crops and to allow the successful implantation of the summer crop.

Determination of the ground cover plants' dry matter (DM) was performed by collecting samples of the aerial part of the plants, using a wooden frame with an area of $0.25 \mathrm{~m}^{2}$. The wooden frame was randomly thrown twice, on the experimental units, in order to the determine sample collection location. The harvested material was oven-dried at $65^{\circ} \mathrm{C}$ until a constant weight was achieved $(72 \mathrm{~h})$. Later, the values obtained were converted to $\mathrm{Mg} \mathrm{ha}^{-1}$, with a mean dry matter production of 5,59 and 4,60 $\mathrm{Mg} \mathrm{ha}^{-1}$ for oat and turnip respectively.

In corn crop seeding $(08 / 10 / 2014)$, a precision Vence Tudo ${ }^{\circledR}$ SM 7040 seeder-fertilizer was used, with a total weight of approximately $1,810 \mathrm{~kg}$, and five lines spaced at $0.7 \mathrm{~m}$ intervals were constructed. Each line was configured with: a smooth cutting disc $0.381 \mathrm{~m}$ in diameter, a shank type furrow opener for fertilizer deposition with a $0.025 \mathrm{~m}$ wide tip and $22^{\circ}$ attack angle, a double disc type furrow opener for seed deposition, seed depth control 
wheels, and conveyor rubber compacting wheels.

An early hybrid Dekalb 240 was used. It features YieldGard PRO2 technology, which produces two Bt (Bacillus thuringiensis) insecticidal proteins. Seeding density was 80,000 plants $^{-1} a^{-1}$ and base fertilization was 400 $\mathrm{kg} \mathrm{ha}^{-1}$ (using a formula ratio of 8-20-15). A further $225 \mathrm{~kg}$ $\mathrm{ha}^{-1}$ of urea was used to cover the area, when most of the plants reached the V4 development stage on the phenological scale.

The area of mobilized soil by the shank type furrow openers in the seeding process was determined with the aid of a profilometer, made of wood, with vertical rods arranged every $0.01 \mathrm{~m}$ transversal to the seeding line. The profile survey of the soil's natural and final surface was obtained by arranging the profilometer, in two distinct locations, in the three central lines of each plot.

The calculation for the area of soil mobilized is outlined in [eq. (1)]:

$$
A s m=\sum\left(P_{N}-P_{F}\right) * e
$$

Where,

Asm - mobilized area $\left(\mathrm{m}^{2}\right)$;

$\mathrm{P}_{\mathrm{N}}$ - profile of natural soil surface for each point of the profilometer, $\mathrm{m}$;

$\mathrm{P}_{\mathrm{F}}$ - profile of the final surface of the soil for each point of the profilometer, $\mathrm{m}$, and

$\mathrm{e}$ - spacing between the vertical rulers, $\mathrm{m}$.

The surface width of the seeding furrow was obtained by determining the distance between the ends of the soil surface disturbed by the action of the shank.

During the corn seeding process, a Campbell Scientific ${ }^{\circledR}$ CR800 data acquisition plate was used to continuously monitor the force at the drawbar required by the seeder-fertilizer, through the signals generated by a Leader Balances ${ }^{\circledR}$ load cell, with a capacity of $50 \mathrm{kN}$, at a frequency of $10 \mathrm{~Hz}$. The load cell was coupled onto the drawbar, connecting the tractor and the header of the seederfertilizer using specific support. The pin that secures the drawbar to the tractor was removed to leave it free to slide, thus applying all the tractive force on the load cell.

The average tractive force at the drawbar was obtained by dividing the sum of the instantaneous tractive force data by the total number of recorded data, according to [eq. (2)]:

$$
F m=\left(\frac{\sum F i}{n}\right)
$$

Where,

$$
\begin{aligned}
& \mathrm{Fm} \text { - average tractive force, } \mathrm{kN} ; \\
& \mathrm{Fi} \text { - instantaneous tractive force, } \mathrm{kN} \text {, and } \\
& \mathrm{n} \text { - number of data recorded. }
\end{aligned}
$$

The mean tractive force at the drawbar per seeding line was obtained by dividing the mean force by the number of seeding lines. The specific tractive force was obtained by dividing the mean force by the mobilized soil area. The velocity of the mechanized set in the seeding process was obtained by measuring the time required for the seeding machine to cover the $15 \mathrm{~m}$ length of the experimental plots, thus obtaining the velocity in $\mathrm{m} \mathrm{s}^{-1}$.

To determine the power at the drawbar [eq. (3)] was used:

$$
P b=F m^{*} V m
$$

Where,

$$
\begin{aligned}
& \mathrm{Pb} \text { - average power at the drawbar, } \mathrm{kW} \text {, and } \\
& \mathrm{Vm} \text { - average speed of the mechanized set, } \mathrm{m} \mathrm{s}^{-1} \text {. }
\end{aligned}
$$

Corn productivity was obtained by harvesting the ears contained within $5 \mathrm{~m}$ of each of the three central lines of each experimental unit. Subsequently, the corn grain mass was corrected to $13 \%$ and the results extrapolated to the area referring to one hectare.

The obtained data was submitted to an analysis of variance test to verify the effects of the following factors using the statistical program GENES: furrow opener shank working depths, ground cover plants, and the interaction between the two. When the $\mathrm{F}$ test presented a significant value $(p \leq 0.05)$ of probability, the averages were compared via the Tukey test $(\mathrm{p} \leq 0.05)$ for the qualitative factors (winter ground cover plants). The polynomial regression test was applied to the quantitative factors (shank working depth) and interactions. The models were selected by the criterion of the highest $R^{2}$ and significance $(p \leq 0.05)$ of the equation parameters.

\section{RESULTS AND DISCUSSION}

All the evaluated parameters presented a significant response regarding the depth of fertilizer deposition by the furrow opener shank, additionally FTE also proved to be dependent on the ground cover plant species. It is observed that the parameters FTE, LSS, ASM, and PM display significant interactions (Table 1). 
TABLE 1. Sources of variation (FV), degrees of freedom (GL), middle square of traction force in the bar (FT), traction force per seeding line (FTL), specific traction force (FTE), average power in the bar (PT), width of furrow surface (LSS), area of soil disturbed (ASM), maize productivity (PM) as a function of the working depth of the furrow opener (Prof.), and ground cover plant species (Cob.)

\begin{tabular}{lcccccccc}
\hline \multicolumn{1}{c}{ FV } & GL & FT & FTL & FTE & PT & LSS & ASM & PM \\
\hline Bloco & 3 & 0.849 & 0.034 & 0.001 & 1.118 & 0.98 & 47.34 & 1.367 \\
Prof. & 3 & $47.838^{*}$ & $1.913^{*}$ & $0.047^{*}$ & $162.564^{*}$ & $11.65^{*}$ & $5556.32^{*}$ & $14.846^{*}$ \\
Erro (a) & 9 & 0.556 & 0.022 & 0.000 & 2.783 & 0.75 & 29.42 & 1.195 \\
Cob. & 1 & 0.002 & 0.000 & $0.008^{*}$ & 0.407 & 3.13 & 114.38 & 1.754 \\
Erro (b) & 3 & 0.319 & 0.013 & 0.001 & 1.667 & 0.90 & 18.61 & 0.283 \\
Prof. x Cob. & 3 & 0.073 & 0.003 & $0.004^{*}$ & 0.578 & $1.81^{*}$ & $147.30^{*}$ & $3.276^{*}$ \\
Residue & 9 & 0.373 & 0.015 & 0.000 & 2.491 & 0.22 & 12.66 & 0.597 \\
Média & & 11.01 & 2.20 & 0.23 & 24.88 & 12.31 & 54.80 & 10.293 \\
\hline C.V. (\%) & & 5.55 & 5.55 & 8.10 & 6.34 & 3.83 & 6.49 & 7.51 \\
\hline
\end{tabular}

*: Significant $(\mathrm{P} \leq 0.05)$. C.V.: coefficient of variation.

The average tractive force required at the drawbar (FT) presented a linear increase which corresponded with the increase in the shank working depth, with values varying from 8.28 to $13.58 \mathrm{kN}$ (Figure $3 \mathrm{~A}$ ). Between the lowest and highest shank working depth there is a $64 \%$ increase in the tractive force required to open the seeding furrow. Similar results were obtained by Tricai et al. (2016), who observed a $63.4 \%$ increase in FT when the furrow opener working depth increased from 0.09 to $0.15 \mathrm{~m}$, in Oxisol with $48 \%$ clay. The authors confirm that the higher tractive force needed is associated with the increase of soil mobilization caused by the deepening of the shank's working.
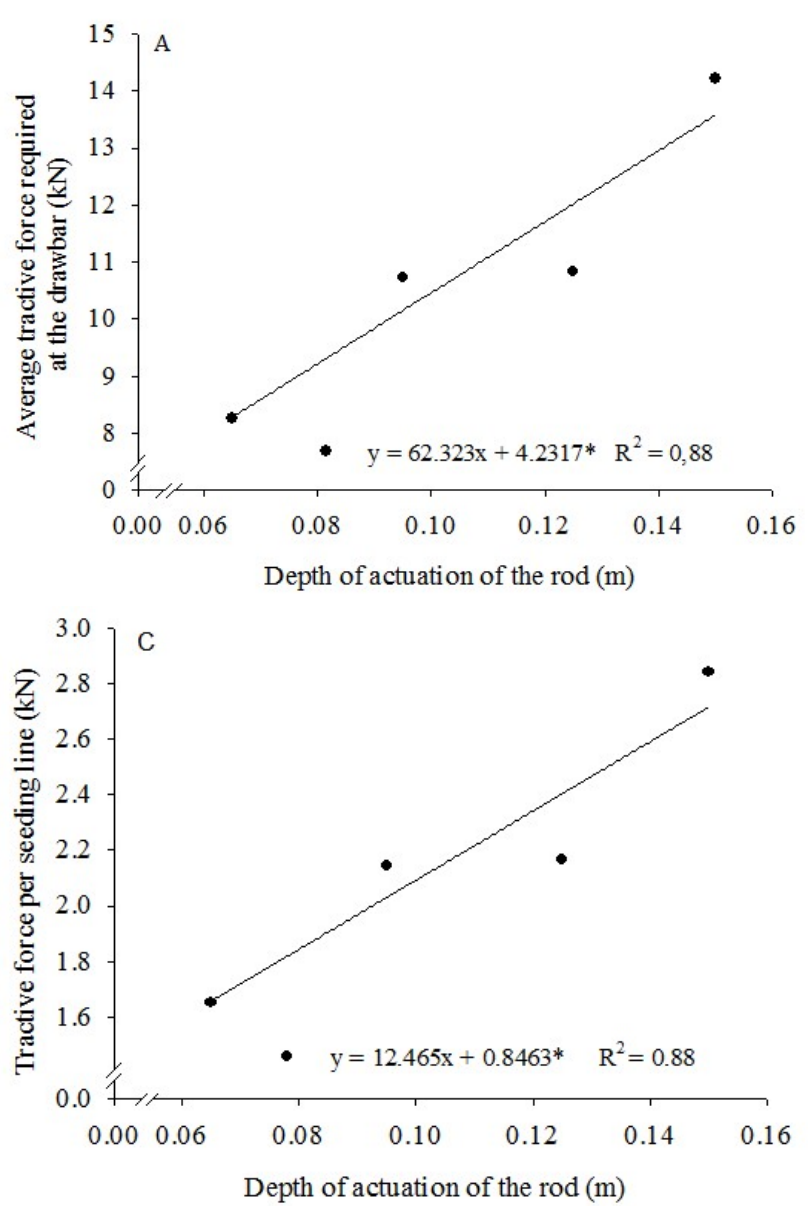

Conte et al. (2009), when analyzing tractive demand and soil mobilization parameters, showed a mean increase of $149 \%$ in tractive force when shank working depths of 0.064 and $0.100 \mathrm{~m}$ were compared. The difference in this percentage and the results obtained in the present study could be associated with the methodology used, since Conte et al. (2009) used electric resistance extensometers installed in the shank furrow opener's support, detecting only the effort that occurred in the shank and neglecting the rolling resistance necessary to draw the rest of the set that composes the seeder.
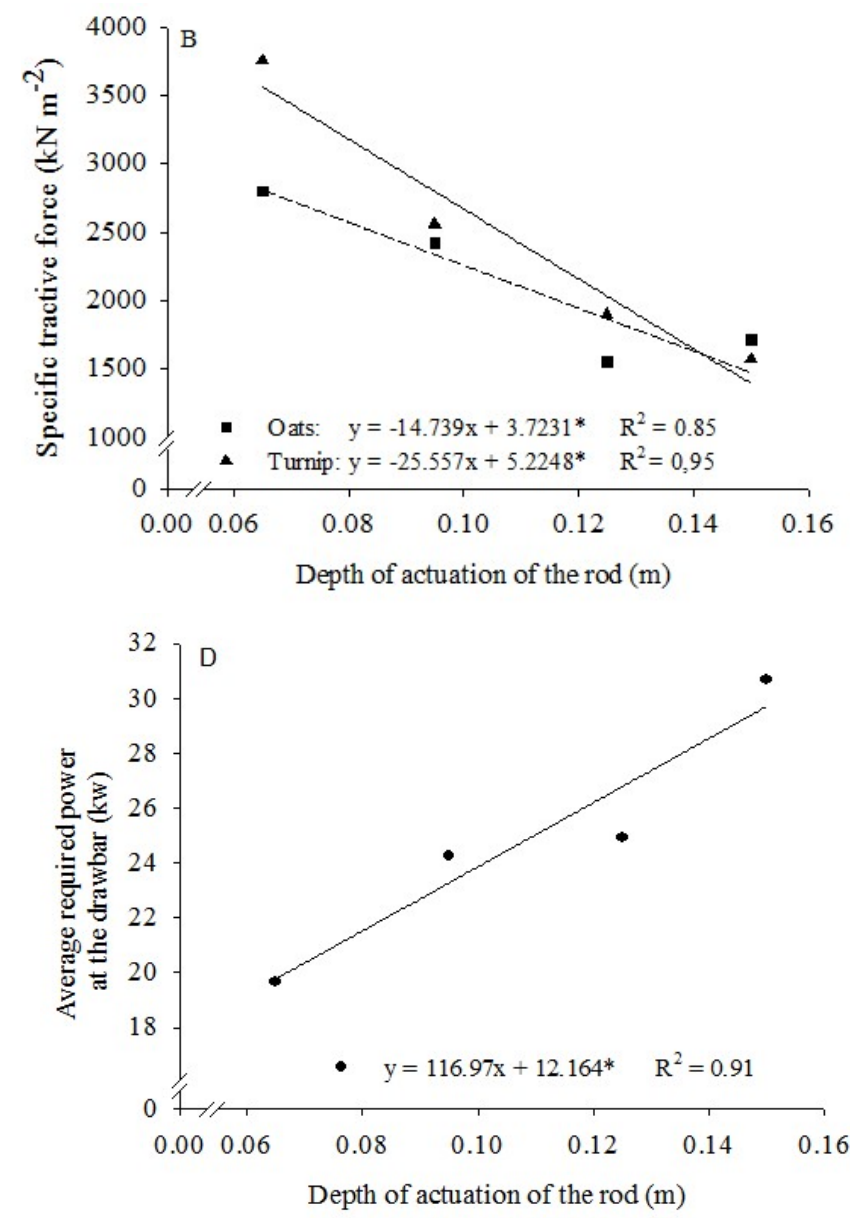

FIGURE 3. Average tractive force required at the drawbar (A), specific tractive force (B), tractive force per seeding line (C), and average required power at the drawbar (D) as a function of fertilizer shank furrow opener working depth and soil cover plants. *: Significant $(\mathrm{P} \leq 0.05)$. 
The specific tractive force (FTE) presented a linear decrease as a function of the furrow opener's working depth and was dependent upon the chosen management of ground cover plants, with values varying from $1,512.25 \mathrm{kN} \mathrm{m}^{-2}$ to $2,765.07 \mathrm{kN} \mathrm{m}^{-2}$ for oats, and from $1,391.25 \mathrm{kN} \mathrm{m}^{-2}$ to $3,563.60 \mathrm{kN} \mathrm{m}^{-2}$ for turnips (Figure 3B). The FTE decreased by $147.39 \mathrm{kN} \mathrm{m}^{-2}$ and $255.57 \mathrm{kN} \mathrm{m}^{-2}$ for each unit $(0.01 \mathrm{~m})$ increase in furrow opener working depth in the areas cultivated with oats and turnips, respectively.

This data shows that the furrow opener working depth of $0.15 \mathrm{~m}$ is a more efficient soil mobilization alternative, since the force $(\mathrm{kN})$ per area $\left(\mathrm{m}^{2}\right)$ was lower when compared to the shank's lower working depths. In this case, when the shank's depth increased from 0.065 to 0.15 $\mathrm{m}$, there was a reduction in FTE of $156.00 \%$ and $82.17 \%$ in the areas managed with forage turnip and black oats, respectively.

Most likely the furrowing opener's critical working depth has not been reached, because of Conte et al. (2011) mention that a drastic FTE increase is expected when this depth is reached, something that did not occur in the data observed in this study.

Tricai et al. (2016) report similar results when evaluating FTE as a function of three depths $(0.09,0.11$ and $0.15 \mathrm{~m}$ ) and two shank inclination angles $\left(17\right.$ and $\left.20^{\circ}\right)$, in Oxisol with $48 \%$ clay. The authors observed that the shank's greatest working depth presented FTE $40 \%$ lower about the lowest working depth.

The mean tractive force required by seeding line (FTL) increased from 1.66 to $2.72 \mathrm{kN}$ when the shank furrow opener worked at the depths of 0.065 and $0.150 \mathrm{~m}$, respectively (Figure $3 \mathrm{C}$ ). The data obtained are within the $3.4 \mathrm{kN}$ value proposed as reference for the tractive force required at the drawbar in an area with immobilized soil (ASAE, 2003).

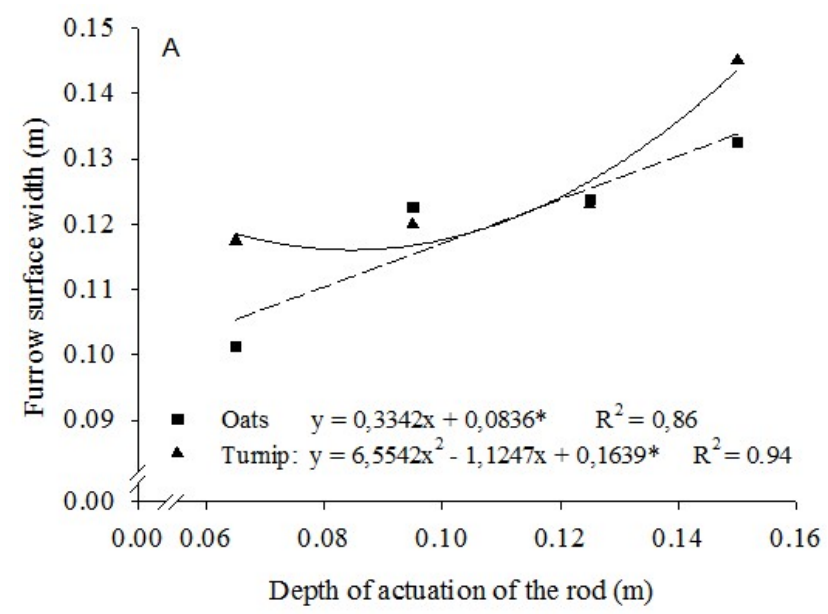

Similar results to those of this study were obtained by Silveira et al. (2011), who, in evaluating machine parameters in Oxisol with $75 \%$ clay, verified an FTL of 2.55 $\mathrm{kN}$, when the tractor/seeder set moved at a speed of $1.28 \mathrm{~m}$ $\mathrm{s}^{-1}$ and with an average shank working depth of $0.105 \mathrm{~m}$.

The average power required at the drawbar (PT) had a linear increase as a function of shank working depth, with values varying from $19.77 \mathrm{~kW}$ to $29.71 \mathrm{~kW}$ (Figure 3D). This trend was a rise in the power required by $1.17 \mathrm{~kW}(1.59$ hp) for each unit $(0.01 \mathrm{~m})$ increase in shank working depth, starting from 0.065 to $0.15 \mathrm{~m}$.

Grotta et al. (2009), when analyzing the energy demand of a seeder-fertilizer as a function of vegetation cover management and the depth of the fertilizer deposition shank, in soil with $51 \%$ clay direct sowing method. The authors found that the PT varied significantly from 22.3 to $24.9 \mathrm{~kW}$ when the shank working depth increased from 0.11 to $0.17 \mathrm{~m}$, with the tractor-seeder set running at a speed of 1.18 and $1.14 \mathrm{~m} \mathrm{~s}^{-1}$, respectively.

Macedo et al. (2016), evaluating the changing energy demand in soil with $10.6 \%$ clay caused by the deepening of the furrow opener shank, found that PT was $12.23,15.5$, and $22.99 \mathrm{~kW}$ when the shank worked at the depths of $0.05,0.10$, and $0.15 \mathrm{~m}$, respectively. These PT results are relatively low compared to the present research and are probably associated with differences in clay content. This is reinforced by Godwin \& O'Dogherty (2007), who mention that soils with low cohesion (sandy) tend to mobilize laterally (two-dimensional) due to the action of shanks. This is because the low capacity of aggregation generates less effort needed from the preparation tools to mobilize the sandy soils compared with the clayey soils (high cohesion).

Figure 4A shows a positive correlation between the furrow surface width (LSS) and the shank's working depth in the area planted with black oats and forage turnip.

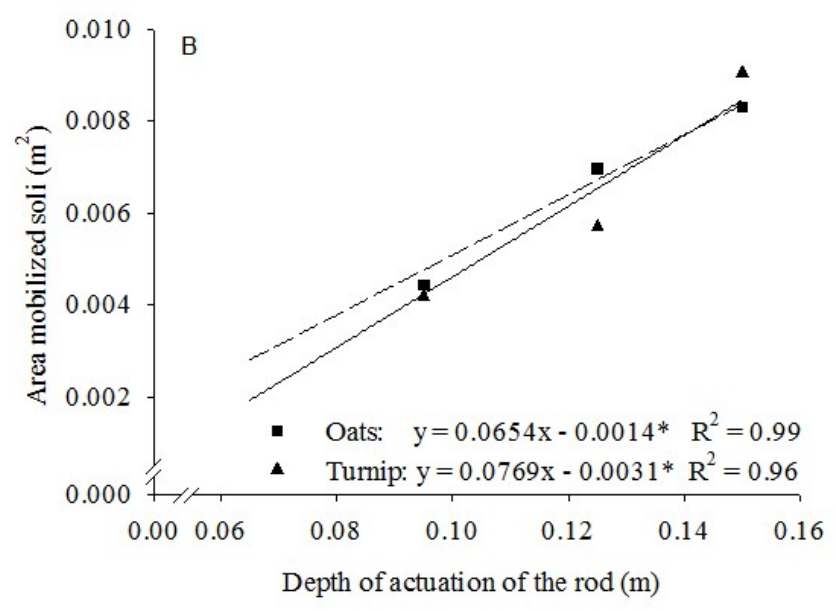

FIGURE 4. Furrow surface width (A) and area of mobilized soil (B) as a function of fertilizer shank furrow opener working depth and winter ground cover crops. *: Significant $(\mathrm{P} \leq 0.05)$. 
In the area managed with forage turnip, the LSS increased from 0.118 to $0.144 \mathrm{~m}$ between the lowest and highest shank working depths. In the area cultivated with black oats, LSS increased from 0.105 to $0.134 \mathrm{~m}$ when the shank working depth increased from 0.065 to $0.15 \mathrm{~m}$. In Figure $4 \mathrm{~A}$, the interactions between the variation sources for the LSS factors were verified, but even with a detailed analysis of the characteristics of the plants and methodological procedures adopted, it was not possible to obtain a diagnosis for this atypical result.

Higher LSS results were reported by Bertonha et al. (2015) who, when analyzing the opening angle of the furrow as a function of the shank working depth $(0.065$, 0.125 , and $0.165 \mathrm{~m}$ ), found that the LSS ranged from 0.160 to $0.206 \mathrm{~m}$, when the lowest shank working depths were compared.

In general, it is stated that the soil mobilization set (the disc plus shank) of the seeder used in this study is adequate in the assumption of low soil mobilization recommended by the direct seeding system. Brandelero et al. (2014), when evaluating different mechanisms for furrow sowing management in direct seeding, verified that the LSS ranged from 0.165 to $0.28 \mathrm{~m}$, when the average furrow depth was 0.049 and $0.081 \mathrm{~m}$, respectively.

This characteristic of low LSS caused by the furrow opener shank, even working at greater depths, is essential because greater mobilized soil surface areas tends to cause increases in soil loss (Volk \& Cogo, 2014), as well as greater weed emergence in the seeding line (Theisen \& Bianchi, 2010).

Concerning the area of mobilized soil (ASM), there is an increase from 0.0028 to $0.0084 \mathrm{~m}^{2}$ according to the shank's working depth, for the black oat. However, the ASM increase observed between the lowest and the highest shank depth, for the cultivation of forage turnip was 0.0019 and $0.0085 \mathrm{~m}^{2}$, respectively (Figure 4B).

The results of the ASM increased due to the deepening of the fertilizer shank, this corroborates with the data published by Cepik et al. (2010). The authors, in evaluating tractive force and soil mobilization via Vence Tudo ${ }^{\circledR}$ seeder-fertilizer shank furrow openers in Ultisol with $20 \%$ clay, verified that the ASM increased from 0.0054 to $0.0065 \mathrm{~m}^{2}$ when the furrow openers operated at the effective depth of 0.065 and $0.115 \mathrm{~m}$, respectively.

In Oxisol with 47\% clay, Bertonha et al. (2015) observed soil mobilization generated by five shank working depths and three shank models with different attack angles (inclined at $15^{\circ}$, straight with an inclined tip at $29^{\circ}$, and parabolic at $27^{\circ}$ ). The authors reported that the shank models did not cause significant variation in soil mobilization. However, the deepening of the shanks to 0.06 , $0.095,0.105,0.12$, and $0.135 \mathrm{~m}$, caused an increase in ASM to $0.0076,0.0120,0.0146,0.0169$, and $0.0192 \mathrm{~m}^{2}$, respectively.

This increase in ASM as a function of the shank's working depth is directly related to the soil structure's rupture behavior. Godwin \& O'Dogherty (2007) state that soil mobilization occurs in a three-dimensional manner (forward, upward, and laterally) when the working depth of the preparation tool does not reach critical working depth.

Concerning the average corn yield (PM), without the adjustment of the data in regards to the regression analysis models tested, there was a significant interaction among factors with the average being $10,293 \mathrm{Mg} \mathrm{ha}^{-1}$.
It is assumed that the failure to obtain significant PM results as a function of the variation in the shank's working depth and management of ground cover plants may be associated with the precipitation and large crop evapotranspiration that occurred during the period of corn crop development (Figure 1).

This result corroborates with data obtained by Debiasi et al. (2010) who analyzed the productivity of soybeans and corn after winter cover and mechanical decompression of the soil. They observed that the cultivation of black oat and forage turnip, in relation to the fallow, provided higher productivity of the crops in the dry season. However, the same result was not repeated in the year that had an absence of water deficit. The authors also verified that the different shank working depths $(0.06$ and $0.12 \mathrm{~m}$ ) did not cause a change in corn productivity during the two years of experimentation.

Similarly to this study, Seki et al. (2015) did not observe any change in corn crop development or productivity when studying the effect of decomposition practices in Oxisol $(60 \%$ clay) by means of subsoiling at $0.40,0.30$, and $0.20 \mathrm{~m}$ depths, before seeding the winter and summer crops, and by the direct seeding of corn with a shank and double disk type furrow opener mechanism.

\section{CONCLUSIONS}

The deepening of the furrow opener shank increased the force and power required at the drawbar in the seeding process.

The deepening of the furrow opener shank also increased the soil mobilization in the seeding line, dependent upon the ground cover plants. However, it did not prove to be an effective management practice for increasing the corn productivity.

\section{ACKNOWLEDGMENTS}

To the CNPq (Research Productivity Grant) and the Araucária Foundation for financial support.

\section{REFERENCES}

Altieri MA, Lana MA, Bittencourt HV, Kieling AS, Comin JJ, Lovato PE (2011) Enhancing crop productivity via weed suppression in organic no-till cropping systems in Santa Catarina, Brazil. Journal of Sustainable Agriculture 35(8):855-869. DOI: http://dx.doi.org/10.1080/10440046.2011.588998

ASAE - American Society of Agricultural Engineers (2003) Agricultural machinery management data: Standards engineering practices data. ASAE, $5 \mathrm{p}$.

Bertonha RS, Furlani CEA, Silva VFA, Wright DL (2015) Tractor performance and corn crop development as a function of furrow opener and working depth in a Red Latosol. Australian Journal of Crop Science 9(9):812-818.

Brandelero EM, Araujo AG, Ralisch R (2014) Mobilização do solo e profundidade de semeadura por diferentes mecanismos para o manejo do sulco de semeadura em uma semeadora direta. Engenharia Agrícola 34(2):263-272. DOI: http://dx.doi.org/10.1590/S010069162014000200008 
Cepik CTC, Trein CR, Levien R, Conte O (2010) Força de tração e mobilização do solo por hastes sulcadoras de semeadoras-adubadoras. Revista Brasileira de Engenharia Agrícola e Ambiental 14(5):561-566. DOI:

10.1590/S1415-43662010000500015

Collares GL, Reinert DJ, Reichert JM, Kaiser DR (2008) Compactação de um Latossolo induzida pelo tráfego de máquinas e sua relação com o crescimento e produtividade de feijão e trigo. Revista Brasileira de Ciência do Solo 32(3):933-942. DOI: http://dx.doi.org/10.1590/S010006832008000300003

Conte O, Levien R, Trein CR, Xavier AAP, Debiasi H (2009) Demanda de tração, mobilização de solo na linha de semeadura e rendimento da soja, em plantio direto. Pesquisa Agropecuária Brasileira 44(10):1254-1261. DOI: http://dx.doi.org/10.1590/S0100-204X2009001000007

Conte O, Levien R, Debiasi H, Sturmer SLK, Mazurana M, Müller J (2011) Soil disturbance index as an indicator of seed drill efficiency in no-tillage agrosystems. Soil \& Tillage Research 114(1):37-42. DOI:

https://doi.org/10.1016/j.still.2011.03.007

Couto RF, Reis EF, Viana PMF, Holtz V, Oliveira LA, Alves SMF (2013) Compactação e recalque superficial de um Latossolo Vermelho em condição de campo e laboratório. Revista Brasileira de Engenharia Agrícola e Ambiental 17(11):1239-1245. DOI: 10.1590/S141543662013001100016

Debiasi H, Levien R, Trein CR, Conte O, Kamimura KM (2010) Produtividade de soja e milho após coberturas de inverno e descompactação mecânica do solo. Pesquisa Agropecuária Brasileira 45(6):603-612. DOI: http://dx.doi.org/10.1590/S0100-204X2010000600010

Feitosa JR, Fernandes HC, Teixeira MM, Cecon PR (2015) Influência da pressão interna dos pneus e da velocidade de deslocamento nos parâmetros operacionais de um trator agrícola e nas propriedades físicas do solo. Engenharia Agrícola 35(1):117-127. DOI:

http://dx.doi.org/10.1590/1809-4430-

Eng.Agric.v35n1p117-127/2015

Godwin RJ, O'Dogherty MJ (2007) Integrated soil tillage force prediction models. Journal of Terramechanics 44(1):3-14. DOI:

https://doi.org/10.1016/j.jterra.2006.01.001

Grotta DCC, Furlani CEA, Silva RP, Lopes A, Reis GN (2009) Semeadora-adubadora: Demanda energética em função do manejo da cobertura vegetal e da profundidade da haste de deposição de adubo em sistema plantio direto. Engenharia Agrícola 29(2):241-248. DOI: http://dx.doi.org/10.1590/S0100-69162009000200007

Gubiani PI, Reichert JM, Reinert DJ (2014) Interação entre disponibilidade de água e compactação do solo no crescimento e na produção de feijoeiro. Revista Brasileira de Ciência do Solo 38(3):765-773. DOI: http://dx.doi.org/10.1590/S0100-06832014000300008
Klein VA (2014) Física do solo. Passo Fundo, Universidade de Passo Fundo, p70-75.

Macedo DXS, Nicolau FEA, Nascimento HCF, Costa E, Chioderoli CA, Loureiro DR (2016) Operational performance of a tractor-seeder according to the velocity and working depth. Revista Brasileira de Engenharia Agrícola e Ambiental 20(3):280-285. DOI: 10.1590/18071929/agriambi.v20n3p280-285

Nunes MR, Denardin JE, Pauletto EA, Faganello A, Pinto LFS (2015) Mitigation of clayey soil compaction managed under no-tillage. Soil \& Tillage Research 148(1):119-126. DOI: https://doi.org/10.1016/j.still.2014.12.007

Palma MAS, Volpato CES, Barbosa JÁ, Spagnolo RT, Barros MM, Vilas Boas LA (2010) Efeito da profundidade de trabalho das hastes sulcadoras de uma semeadoraadubadora na patinagem, na força de tração e no consumo de combustível de um trator agrícola. Ciência e Agrotecnologia 34(5):1320-1326. DOI: http://dx.doi.org/10.1590/S1413-70542010000500034

Sanchez E, Maggi MF, Genú AM, Muller MML (2012) Plantas de cobertura de inverno, produção de biomassa vegetal e resistência do solo. Pesquisa Aplicada \& Agrotecnologia 5(3):33-40. DOI: http://dx.doi.org/10.5777/PAeT.V5.N3.04

Santos FS, Zanão Junior LA, Secco D, Dias PP, Tomassoni F, Pereira NA (2014) Utilização de plantas de cobertura na recuperação de solos compactados. Acta Iguazu 3(3):82-91.

Seki AS, Seki FG, Jasper SP, Silva PRA, Benez SH (2015) Effects of soil decompaction techniques in an area under a system of direct seeding. Revista Ciência Agronômica 46(3):460-468. DOI: http://dx.doi.org/10.5935/18066690.20150027

Silveira JCM, Fernandes HC, Silva SL. Modolo AJ, Trogello E (2011) Furrow depth, soil disturbance area and draft force of a seeder-fertilizer at different seeding speeds. Revista Ceres 58(3): 293-298. DOI: http://dx.doi.org/10.1590/S0034-737X2011000300008

Soil Survey Staff (2014) Keys to soil taxonomy. Department of Agriculture. Natural Resources Conservation Service, 12 ed. 372p.

Theisen G, Bianchi MA (2010) Semeadura com pouco revolvimento de solo como auxilio no manejo de plantas daninhas em milho. Planta Daninha 28(1):93-102. DOI: http://dx.doi.org/10.1590/S0100-83582010000100012 
Thornthwaite CW (1948) An approach toward a rational classification of climate. Geographical Review 38(1):5594. DOI: http://dx.doi.org/10.2307/210739

Tricai E, Furlani CEA, Bertonha RS, Silva VFA, Compagnon AM, Cassia MT (2016) Energy demand of furrow openers and corn yield according to the soil disturbance in no till system. African Journal of Agricultural Research 11(17):1538-1542. DOI: http://dx.doi.org/10.5897/AJAR2015.8789
Valadão FCA, Weber OLS, Valadão Júnior DD, Scapinelli A, Deina FR, Bianhini A (2015) Adubação fosfatada e compactação do solo: sistema radicular da soja e do milho e atributos físicos do solo. Revista Brasileira de Ciência do Solo 39(1):243-255. DOI:

http://dx.doi.org/10.1590/01000683rbcs20150144

Volk LBS, Cogo NP (2014) Erosão hídrica, em três momentos da cultura do milho, influenciada por métodos de preparo do solo e semeadura. Revista Brasileira de Ciência do Solo 38(2):565-574. DOI: http://dx.doi.org/10.1590/S0100-06832014000200021 